\title{
Development of multilingual thematic picture dictionary: A support for literacy
}

\author{
Ni Made Suniyasih",*, Ni Made Ratminingsih², I Gede Budasi ${ }^{3}$ \\ 1,2,3 Department of English Language Education, Universitas Pendidikan Ganesha, Jalan A. Yani, Singaraja, Bali, \\ Indonesia \\ *Corresponding author: ni.made.suniyasih@undiksha.ac.id
}

\begin{abstract}
The study aimed at developing a multilingual thematic picture dictionary as a media to support literacy in English language for fifth grade elementary school students in Bali. This study used Design and Development (D\&D) model by Richey and Klein (2014). The steps were (1) analysis, (2) design, (3) development, and (4) evaluation. Fifth grade elementary school students and English teachers from rural and urban area were the research subjects. They were chosen through purposeful sampling technique. In analysis, the data were collected through observation, interview, questionnaire, and document analysis. The result of needs analysis found that there is an urgency of developing multilingual thematic picture dictionary. The students needed dictionary while learning English because it helped them in finding the word's meaning independently and could help them prepare for additional point while participating in teaching learning process content validity judgment showed that the dictionary was highly valid to criteria of a good multilingual thematic picture dictionary. The result showed that the multilingual thematic picture dictionary was categorized as 'excellent' media. Thus, it can be used as a media to support fifth grade elementary school students in developing their literacy skills.
\end{abstract}

Keywords: dictionary; literacy; young learners

\section{Introduction}

Literacy is an important foundation skill for success in school and life. Having a high level of literacy can increase academic success, future career, motivation to learn, and selfesteem, and efficacy (Carroll et al., 2019; Salim et al., 2018). In this $21^{\text {st }}$ century of education, literacy means being capable not just in reading and writing, but also being capable intellectually, culturally, and electronically (Chalkiadaki, 2018; Eryansyah et al., 2019; Greene, 2018). Therefore, it is important to teach literacy skill as early as possible.

In reality, Indonesian students' literacy becomes one of the biggest problems that education in Indonesia has faced. Indonesian students had been tested with PISA (Programmed for International Students Assessment) from 2000 until 2018. This program assessed students' abilities in reading, mathematics, and science and also is used as an assessment for parameter of the impact of education policy decisions (Hipkins, 2019; Hopfenbeck, 2016). Based on the test result in 2018, Indonesian students had average score about 371 in reading which was under Organization for Economic Co-Operation and Development (OECD) average score 487 (OECD, 2019). The test result score in 2018 decreased from the past result score in 2015 which was 397. This place Indonesian students' literacy skill at $60^{\text {th }}$ from 61 countries. Studies had also identified that Indonesian students' 
literacy is still low and it requires significant improvement (Dewantara et al., 2019; Gustine, 2018; Supratman \& Wahyudin, 2020). Therefore, literacy improvement policies and strategies need to be developed immediately.

There are several factors that influence students' low level of literacy in Indonesia. The factors are rapid development of entertainment media, family involvement, interaction with others, library program failure, social-politic problem, lack of motivation and engagement, and socio cultural environment (Abrori, 2018; Dewi et al., 2019). Since literacy skills has strong relation with reading, those factors can reflect the factors of students' literacy skills as well (Maharsi et al., 2019; Mckinnon, 2017). Thus, it showed that the factors of Indonesian students' low literacy skills came from the inner and outer of the students itself.

It is believed that developing literacy skill should be started at early age. This idea was supported by experts that see the benefit of developing literacy skill as early as possible (Ólafsdóttir et al., 2020; Taylor \& Leung, 2020; Trainin et al., 2017). Teaching literacy in early age should focus on concrete concept, meaningful, interesting, functional and engaging (Huh \& Suh, 2017; Ratminingsih \& Budasi, 2018). Literacy teaching to children can be started by teaching the smallest elements of a language, namely vocabulary. Through enhancing vocabulary, students can build their literacy skill (Lelawati et al., 2018; J. Li et al., 2017; Stoffelsma, 2019). Therefore, it showed that vocabulary is important to be mastered in order to develop elementary school students' literacy skill.

Considering the important role of vocabulary in developing literacy, it becomes the reason why vocabulary needs to be taught by using an effective teaching media. A dictionary can selected as one media to enhance students' vocabulary mastery (Alhatmi, 2019; Deng \& Trainin, 2020; Q. Li, 2019). The use of dictionary can help the students by providing sources of words, meaning and pronunciation and it also assists them enhancing vocabulary mastery (Abbasi et al., 2019; Barham, 2017). Furthermore, students can use dictionary to find meaning, looking for translation, synonym, and paraphrasing (Nematollahi et al., 2017; Tsai, 2019). Besides that, dictionary provides the students knowledge about phonetics, word roots, and grammar (Tulgar, 2017). It can be said that dictionary is essential media in learning vocabulary.

There were three kinds of dictionary focused in this current research, namely; multilingual dictionary, thematic dictionary, and picture or visual dictionary. Multilingual dictionary is a dictionary which provides a list of words of more than two languages (Bask \& Mumcu, 2018; Yurtbaǵ1, 2017). Thematic dictionary is a dictionary which consists of simple 
words that come from a certain theme and sometimes followed by graphic or illustration (Biesaga, 2017). Meanwhile, picture or visual dictionary is a dictionary which adds pictures to visualize the meaning of words and mostly provides nouns (Smith et al., 2016).

Based on preliminary observation which had been conducted at two elementary schools in Bali, there is a phenomenon which is a lot of urban students do not know Balinese and a lot of rural students do not know Bahasa Indonesia. When rural students tried to find out a meaning of a word in the bilingual dictionary, they still did not understand. This happened because mostly the dictionary in Bali is bilingual (English-Bahasa Indonesia and Bahasa Indonesia-English). Moreover, students' perception about bringing the common printed dictionary was useless because it was ineffective. It affected the rural students to not bring dictionary in teaching and learning process. Moreover, students are not allowed to bring gadgets due to their school rule. Thus, it is important to develop an attractive and interactive printed dictionary for elementary school students.

Previously, there were several studies conducted in relation with dictionary development. Sibanda (2019) found an effective dictionary should provide translation of target language in students' native language. A study conducted by Rahim and Chun (2017) found that a visual or picture dictionary is very effective helping students to understand the meaning of a word, the pronunciation and the visual of the image of the word. Muslimin and Surjono (2018) developed a dictionary which consist of local language translation. Santosa and Andriyadi (2019) found that the use of dictionary is able to enhance students' vocabulary master.

Based on aforementioned background stated above, this research aimed at developing multilingual thematic picture dictionary for fifth grade elementary school students. The dictionary provided words in three languages namely English, Bahasa Indonesia, and Balinese. The words were based on the theme in syllabus of fifth grade elementary school students. Furthermore, this dictionary provided picture in order to visualize the words. This multilingual thematic picture dictionary would be in printed form due to the prohibition in bringing smartphone.

\section{Materials and Methods}

The design of this research was a Design and Development (D\&D) model by (Richey $\&$ Klein, 2014). In this model, there were four stages, namely; analysis, design, development, and evaluation. The analysis stage aimed at collecting several information that was related to the needs of the subject. The subjects of this research were the fifth grade elementary school 
students and teacher from rural area and urban area. The subjects of the research were chosen through purposeful sampling technique.

The result of observation, interview, questionnaire, and document analysis were analyzed qualitatively. In designing stage, draft of the final product was designed after analyzing the subject's needs. The draft reflected the result of the analysis. The development referred to the process in developing the draft into the final product. After analysis, design, and development, evaluation came at last in order to evaluate the final product. It was done through content validity judgment and quality judgment by expert judges and users. The result of content validity judgment was analyzed through Gregory formula. Meanwhile, the result of quality judgment was analyzed using guidance developed by Pallant (2016).

\section{Results and Discussion}

The result of observation showed that both schools in rural and urban area did not have a multilingual thematic picture dictionary in their library and in their classroom. Besides, the result of the observation also showed that both students and teachers used dictionary in classroom rarely. Furthermore, there were three main points found in the result of teachers' interview. First, the teacher realized the importance of teaching English and vocabulary for the fifth grade elementary school students because it was the basis for them to learn more in the future. Second, the teacher never used dictionary in teaching learning process because of the small number of students who brought dictionaries and the language level for elementary school was still capable to teach without dictionary. Third, the use of dictionary was important because it helped students to learn English in school or even in their house. Dictionary also helped the teacher in convincing the students and rechecking the meaning of a word.

From the students' interview, it was important for them to learn English and its vocabulary because it could help them to get a job, increase the self-esteem, and learn other culture. Second, they did not regularly bring dictionary and students were easy to forget the form of the words. Third, they needed dictionary while learning English because it helped them in finding the word's meaning independently and could help them prepare for additional point while participating in teaching learning process. The first point was related to the necessities which was what the fifth grade elementary school students must know and get in learning English. The second was related to the lacks which was the gap between what they must know with the reality that they face. The third was related to the wants which described what the students' needs, wants, and hopes in learning English. 
The questionnaire was divided into 11 statements. It was delivered to 128 students at SDN 1 Busung Biu and SDN 3 Banjar Jawa. The result of the questionnaire is presented in table 2 .

Table 2. The Result of Questionnaire

\begin{tabular}{|c|c|c|c|}
\hline $\begin{array}{c}\text { How (the method used in } \\
\text { learning) }\end{array}$ & $\begin{array}{c}\text { What (the media used in } \\
\text { learning) }\end{array}$ & \multicolumn{2}{|c|}{ Who (the need) } \\
\hline Playing game $(91 \%)$ & 6. Using English textbook (89\%) & \multicolumn{2}{|c|}{ 11. Need dictionary in } \\
\hline Singing English song (78\%) & 7. Using students worksheet (66\%) & \multirow{4}{*}{$\begin{array}{l}\text { learning } \\
(92 \%)\end{array}$} & \multirow{4}{*}{ English } \\
\hline Observing picture (88\%) & 8. Using dictionary $(91 \%)$ & & \\
\hline Watching video (76\%) & 9. Using outline $(86 \%)$ & & \\
\hline $\begin{array}{l}\text { Listening to teacher's } \\
\text { explanation }(87 \%)\end{array}$ & 10. Using exercise $(81 \%)$ & & \\
\hline
\end{tabular}

The table shows from the 'how' aspect most of students liked to learn English through playing game. Then, the 'what' aspect showed that most of students liked to learn English by using dictionary, while the 'who' aspect showed that $92 \%$ students need dictionary in learning English. Thus, it can be concluded that the fifth grade elementary school students need appropriate media called dictionary in teaching learning process.

In developing the multilingual thematic picture dictionary, this current study adopted and modified Chaer's steps in developing dictionary. The draft was constructed with 10 themes with the words in English, Bahasa Indonesia, and Balinese. As well, it was complemented with authentic pictures. Then, the next step was developing the draft into the final product. The dictionary was divided into two parts namely dictionary cover and list of words. The dictionary had 96 pages in total. Then, the dictionary was judged for the content validity by two experts. The first expert was an expert for English and Bahasa Indonesia. The second expert was an expert for Balinese. The result of the content validity was analysed through Gregory formula. The result of content validity judgment showed that the dictionary was relevant with 11 criteria of a good multilingual thematic picture dictionary. However, there were still some revisions in certain parts of the dictionary. The first part was the cover dictionary. The cover did not reflect Balinese culture. Since, the dictionary was developed for English language learners in Bali, it should represent their nearest environment to make the learning become contextual and meaningful.

The second revision was about the picture. There were 19 pictures revised. The pictures were revised because of some reasons. First, the picture did not represent Balinese culture completely. Second, the picture did not signify the sentence. Third, the picture was revised because the picture did not show the authenticity of students' real life environment. Furthermore, according to the criteria of a good multilingual thematic picture dictionary, the dictionary's picture should be authentic (concrete), appropriate, positive, clear, and colourful. 
Afterward, the third revision was about the sentences. They were revised because of several reasons. First, it was about singular and plural error. Second, it was about grammatical error. Third, it was about the relation between the picture and the sentence. Fourth, it was about typographical error. Therefore, there were 40 sentences revised.

After revising some parts of the dictionary, it was judged for the quality of the product by three experts and two users. The result of the quality judgment is shown in table 3.

Table 3. The Result of Quality Judgment

\begin{tabular}{ccc}
\hline Experts/Users & Score & Category \\
\hline Expert 1 & 49 & Good \\
\hline Expert 2 & 53 & Excellent \\
\hline Expert 3 & 51 & Excellent \\
\hline User 1 & 53 & Excellent \\
\hline User 2 & 53 & Excellent \\
\hline
\end{tabular}

The table showed that the total score given by first expert was 49 which was categorized as good. The second expert, third expert, first user, and second user gave 53, 51, 53, and 53 as the total score which was categorized as excellent.

From the research results obtained, it can be said that the need for a dictionary is very urgent. This is also in line with research conducted by which found that dictionaries have a very important role in the language learning process (Alhatmi, 2019; Muslimin \& Surjono, 2018; Rahim \& Chun, 2017). This study also found that the quality of a dictionary is also very important in order to provide correct and accurate knowledge to students. The results of the research conducted by Barham (2017) who confirmed that a dictionary must really contain elements that can help students master the vocabulary of their main language in foreign languages.

The dictionary developed in this study is a multilingual thematic picture dictionary. The dictionary developed in this study contains three languages, namely Indonesian, Balinese and English. Using more than one language source according to it will train students to read more and indirectly will improve their literacy skills (Abbasi et al., 2019; Muslimin \& Surjono, 2018). In addition, the dictionary developed also contains images that provide visuals to students. The results of the research conducted by Biesaga (2017) who found that children will be more interested in reading if the reading material contains visual elements. This is also identified by those who find that students' reading interest will be higher if they are given a concrete concept and it is in accordance with their learning method (Ratminingsih \& Budasi, 2018; Sibanda, 2019). From the results of the assessment provided by the expert, the dictionary developed in this study can be categorized as very good. This means that the 
dictionary contains elements that can help students learn vocabulary and improve their ability to use English words. This is also in line with a study conducted by Santosa and Andriyadi (2019) who found that attractive and good quality of dictionary helps the students to add their vocabulary list and boost their vocabulary mastery.

\section{Conclusion}

The study found that the fifth-grade elementary school students' needs in learning English was an appropriate media called dictionary to support their literacy skill. The dictionary was designed based on the result of observation, interview, questionnaire, and document analysis. There were two steps in developing the dictionary, namely designing the dictionary draft and developing the draft into final product. As the result, the product of this study was a multilingual thematic picture dictionary for the fifth-grade elementary school students of SDN 1 Busung Biu and SDN 3 Banjar Jawa in Buleleng Regency North Bali. The dictionary was evaluated by three experts and two users which the result showed that the multilingual thematic picture dictionary was categorized as "excellent" media. Thus, the multilingual thematic picture dictionary can be used as a media to support literacy in English language class for fifth grade elementary school students. It is suggested for the students and teacher to use the dictionary in teaching learning process. Moreover, it is suggested for other researchers to continue this study by conducting field implementation and to develop the dictionary into a better product which provides pronunciation, definition, spelling, synonym, antonym, and parts of speech.

\section{References}

Abbasi, W. T., Ahmad, M. M., \& Mohammed, F. A. E. (2019). Learners ' Perceptions of Monolingual Dictionaries in Learning English as a Foreign Language. International Journal of Education \& Literacy Studies, 7(3), 10-18.

Abrori. (2018). Improving Reading Literacy Strategy through Seven Programs of Reading Interest $\mathrm{c}$ ontaining $\mathrm{Da}$ ' wah Message. Attarbiyah: Journal of Islamic Culture and Education, 3(2), 205-225. https://doi.org/10.18326/attarbiyah.v3i2.205-225

Alhatmi, S. (2019). A Survey Study of the Dictionary Use Sub-strategies of English Majors in Saudi Arabia: Dictionary Related Aspects. English Language Teaching, 12(3), 139160. https://doi.org/10.5539/elt.v12n3p139

Barham, K. A. (2017). The Use of Electronic Dictionary in the Language Classroom: The Views of Language Learners. The Second International Conference for Learning and Teaching in the Digital World $\backslash, 1-12$.

Bask, S., \& Mumcu, M. (2018). Dictionary Culture of University Students Learning English as a Foreign Language in Turkey. International Education Studies, 11(3), 101-114. https://doi.org/10.5539/ies.v11n3p101 
Biesaga, M. (2017). Dictionary Tradition vs. Pictorial Corpora : Which Vocabulary Thematic Fields Should Be Illustrated ? Lexikos, 27, 132-151. https://doi.org/10.5788/27-1-1397

Carroll, J. M., Holliman, A. J., Weir, F., \& Baroody, A. E. (2019). Literacy interest, home literacy environment and emergent literacy skills in preschoolers. Journal of Research in Reading, 42(1), 150-161. https://doi.org/10.1111/1467-9817.12255

Chalkiadaki, A. (2018). A Systematic Literature Review of 21 st Century Skills and Competencies in Primary Education. International Journal of Instruction, 11(3), 1-16. https://doi.org/10.12973/iji.2018.1131a

Deng, Q., \& Trainin, G. (2020). Self-Efficacy and Attitudes for Vocabulary Strategies Among English Learners and Native Speakers Self-Efficacy and Attitudes for Vocabulary Strategies Among. Reading Horizons : A Journal of Literacy and Language Arts, 59(1), 41-69.

Dewantara, I. P. M., Suandi, I. N., Rasna, I. W., \& Putrayasa, I. B. (2019). Cultivating Students' Interest and Positive Attitudes towards Indonesian Language through Phenomenon-Text-Based Information Literacy Learning. International Journal of Instruction, 12(2), 147-162. https://doi.org/10.29333/iji.2019.12210a

Dewi, C. A., Khery, Y., \& Erna, M. (2019). An Ethnoscience Study in Chemistry Learning to Develop Scientific Literacy. Jurnal Pendidikan IPA Indonesia, 8(2), 279-287. https://doi.org/10.15294/jpii.v8i2.19261

Eryansyah, Erlina, Fiftinova, \& Nurweni, A. (2019). EFL Students 'Needs of Digital Literacy to Meet the Demands of 21 st Century Skills. Indonesian Research Journal in Education, 3(2), 442-460.

Greene, K. (2018). Trasnferable Digital Literacy Knowledge. The Language and Literacy Spectrum, 28(1), 1-15.

Gustine, G. G. (2018). A Survey on Critical Literacy as a Pedagigical Approach to Teaching English in Indonesia. Indonesian Journal of Applied Linguistics, 7(3), 531-537. https://doi.org/10.17509/ijal.v7i3.9798

Hipkins, R. (2019). Thinking critically about PISA. SEt, 2, 49-52. https://doi.org/10.18296/set.0143

Hopfenbeck, T. N. (2016). The power of PISA - limitations and possibilities for educational research. Assessment in Education: Principles, Policy \& Practice, 23(4), 423-426. https://doi.org/10.1080/0969594X.2016.1247518

Huh, S., \& Suh, Y. (2017). Preparing elementary readers to be critical intercultural citizens through literacy education. Language Teaching Research, 22(5), 1-20. https://doi.org/10.1177/1362168817718575

Lelawati, S., Dhiya, S., \& Mailani, P. N. (2018). The Teaching of English Vocabulary to Young Learners. Professional Journal of English Education, 1(2), 95-100.

Li, J., Cummins, J., \& Deng, Q. (2017). The effectiveness of texting to enhance academic vocabulary learning: English language learners ' perspective. Computer Assisted Language Learning, 30(8), 1-28. https://doi.org/10.1080/09588221.2017.1366923

Li, Q. (2019). Empirical Research on Pedagogical Dictionary Use in Recent 30 Years. Journal of Education and Learning, 8(6), 103-109. https://doi.org/10.5539/jel.v8n6p103

Maharsi, I., Ghali, M. I., \& Maulani, S. (2019). High School Students' Reading Habit and Perception on Reading for Pleasure. International Journal of Indonesian Education and 
Teaching, 3(1), 80-89. https://doi.org/10.24071/ijiet.2019.030108

Mckinnon, D. (2017). Early Years Literacy Instruction. Journal of Graduate Studies in Education, 9(1), 32-37.

Muslimin, I., \& Surjono, H. D. (2018). Developing Bima-Indonesia Mobile Dictionary with Input-Output Google Voice Feature. IOP Conf. Series: Journal of Physics: Conf. Series, 1-11. https://doi.org/10.1088/1742-6596/1140/1/012044

Nematollahi, B., Behjat, F., \& Kargar, A. A. (2017). A Meta-Analysis of Vocabulary Learning Strategies of EFL Learners. English Language Teaching, 10(5), 1-10. https://doi.org/10.5539/elt.v10n5p1

Ólafsdóttir, S., Laster, B., \& Stefánsson, K. K. (2020). Adolescent Learning of Academic Vocabulary in Iceland. Journal of Adolescent \& Adult Literacy, 64(1), 79-87. https://doi.org/10.1002/jaal.1055

Pallant, J. (2016). SPSS Survival Manual: A Step by Step Guide to Data Analysis Using IBM SPSS. Open University Press.

Rahim, F. A., \& Chun, L. S. (2017). Proposing an affective literacy framework for young learners of English in Malaysian rural areas: Its key dimensions and challenges. Malaysian Journal of Learning and Instruction, 14(2), 115-144.

Ratminingsih, N. M., \& Budasi, I. G. (2018). Local culture-based picture storybooks for teaching English for young learners. GC-TALE, 1-6. https://doi.org/10.1051/shsconf/20184200016

Richey, R., \& Klein, J. (2014). Design and Development Research. In M. Spector, D. Merrill, J. Elen, \& M. Bishop (Eds.), Handbook of Research on Educational Communications and Technology (pp. 141-150). Springer.

Salim, S. F. M. Y. S., Mahmood, M. F., \& Ahmad, A. B. (2018). The Importance of Information Literacy to Support Lifelong Learning in Convergence Era. International Journal of Academic Research in Progressive Education and Development, 7(3), 352362. https://doi.org/10.6007/IJARPED/v7-i3/4372

Santosa, I., \& Andriyadi. (2019). The Use of My Dictionary Applicatin to Improve Students' Vocabulary Master. ELTIN Journal, 7(1), 35-42.

Sibanda, R. (2019). Mother-tongue education in a multilingual township: Possibilities for recognising lok'shin lingua in South Africa. Reading \& Writing, 10(1), 1-46.

Smith, S., Sanchez, C., Betty, S., \& Davis, S. (2016). Processing Academic Language Through Four Corners Vocabulary Chart Applications. The CATESOL Journal, 28(1), 69-80.

Stoffelsma, L. (2019). From ' sheep ' to ' amphibian ': English vocabulary teaching strategies in South African township schools. South African Journal of Childhood Education, 9(1), 1-10. https://doi.org/10.4102/sajce.v9i1.650

Supratman, L. P., \& Wahyudin, A. (2020). Digital Media Literacy to Higher Students in Indonesia. International Journal of English Literature and Social Sciences, 2(5), 51-58. https://doi.org/10.24001/ijels.2.5.7

Taylor, S. V, \& Leung, C. B. (2020). Multimodal Literacy and Social Interaction : Young Children' s Literacy Learning. Early Childhood Education Journal, 48, 1-10. https://doi.org/10.1007/s10643-019-00974-0 
Trainin, G., Wessels, S., Nelson, R., \& Vadasy, P. (2017). A Study of Home Emergent Literacy Experiences of Young Latino English Learners. Early Childhood Education Journal, 45, 651-658. https://doi.org/10.1007/s10643-016-0809-7

Tsai, K. (2019). Corpora and dictionaries as learning aids: inductive versus deductive approaches to constructing vocabulary knowledge. Computer Assisted Language Learning, O(0), 1-22. https://doi.org/10.1080/09588221.2018.1527366

Tulgar, A. T. (2017). Dictionary Use of Undergraduate Students in Foreign Language Departments in Turkey at Present. Universal Journal of Educational Research, 5, 5157. https://doi.org/10.13189/ujer.2017.051406

Yurtbaǵ1, M. (2017). A Multilingual Dictionary also Containing Qazaq Terminology in Phonetics and Phonology. International Journal of Arts Humanities and Social Sciences, 2(11), 78-103. 